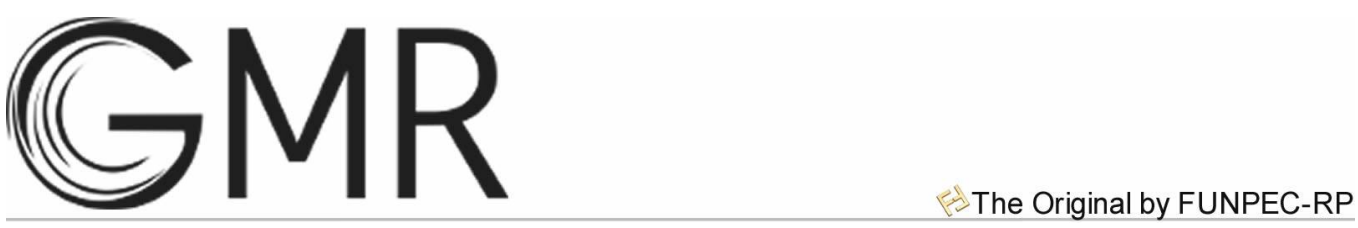

\title{
Analysis of genetic divergence in sweet corn genotypes through hierarchical optimization methods
}

\author{
F.J. Carvalho ${ }^{1}$, G.M. Maciel ${ }^{2}$, O.J. Marques ${ }^{2}$, I.G. da Silva ${ }^{2}$, \\ G.D. Braga ${ }^{2}$, G.R. Marquez ${ }^{2}$, A.C.S. Siquieroli ${ }^{2}$ and L.D.C. Neto ${ }^{2}$ \\ ${ }^{1}$ Instituto Federal do Triângulo Mineiro, Uberaba, MG, Brasil \\ ${ }^{2}$ Instituto de Ciências Agrárias, Universidade Federal de Uberlândia, Monte \\ Carmelo, MG, Brasil
}

Corresponding author: F.J. Carvalho

E-mail: fabiojanoni@ufu.br

Genet. Mol. Res. 18 (3): gmr18384

Received March 07, 2019

Accepted July 11, 2019

Published August 22, 2019

DOI http://dx.doi.org/10.4238/gmr18384

\begin{abstract}
Sweet corn (Zea mays subsp. saccharata) is considered a special vegetable of high nutritional value. One of the barriers encountered by breeders has been a lack of adequate genetic variability of sweet corn, coupled with a need for appropriate methodologies to evaluate the existing genetic diversity. Our objective was to determine the best method to identify promising genotypes to improve sweet corn production. We used data from 181 open-pollinated sweet corn genotypes, cultivated during 2016 and 2017. Multivariate analyses were carried out to determine the genetic dissimilarity between the genotypes, obtaining the matrix of dissimilarity by Euclidean distance. Prior to calculating the distance between matrices, two data standardizations $\left(Z_{1}\right.$ and $\left.Z_{2}\right)$ were performed for comparison. Genetic divergence was analyzed by four distinct hierarchical methods: Unweighted Pair-Group Method Using Arithmetic Averages (UPGMA), Ward, Weighted Pair-Group Method Using Arithmetic Averages (WPGMA) and Single Linkage. Tocher's optimization method was also used. The Simple Linkage and UPGMA methods presented similar groupings, consistent with breeding program aims and with the highest values of co-phenetic correlation coefficient (CCC). The Ward's method was not efficient,
\end{abstract}


because it produced several clusters without isolating different genotypes. Furthermore, it was the method with the lowest CCC for both matrices. The standardized $\mathrm{Z}_{2}$ matrix should be avoided, especially when a large number of genetic traits are measured, in order to prevent possible overlapping between traits, a variables with higher standard variations could contribute more to the clustering.

Key words: Genetic diversity; Genetic breeding; Data standardization; Zea mays subsp. saccharata

\section{INTRODUCTION}

Sweet corn (Zea mays subsp. saccharata) is considered a special vegetable of high nutritional value. In Brazil, about US\$ 7.1 million were traded in sweet corn seeds, occupying approximately 50 thousand hectares in 2012 (ABCSEM, 2014). It is worth mentioning that the commercial cropping of sweet corn does not meet the current Brazilian demand (Moterle et al., 2012; Ribeiro et al., 2012; Vittorazzi et al., 2013). Sweet corn has distinct characteristics compared to common green corn (Pena et al., 2012), with reduced genetic variability available for direct use in breeding programs. Recurrent selection methods have been successfully applied (Amaral Junior et al., 2013; Freitas et al., 2013) to later obtain simple hybrids (Rangel et al., 2017). One of the barriers encountered by breeders has been the relatively low genetic variability of sweet corn, coupled with a lack of appropriate methodologies to evaluate the existing genetic diversity. Genetic variability determines the feasibility of a breeding program, being potentiated by cross-linking between contrasting genotypes (Silva et al., 2011; Ertiro et al., 2013; Silva and Dias, 2013; Fernandes et al., 2015; Silva et al., 2016).

Multivariate techniques have been used to estimate the genetic divergence between accessions, like biometric models estimated by the Euclidean Distance and hierarchical grouping methods (Cruz et al., 2014). However, there is no consensus regarding the best cluster analysis method to evaluate sweet corn germplasm. Also, for the characters to be estimated by the matrices data standardization is necessary; few studies have evaluated the impact of different data transformation methods.

When evaluating green corn genotypes, Silva et al. (2016) verified that the UPGMA method was more sensitive to detect differences between genotypes and consequently to form groups. In contrast, Rigon et al. (2015) evaluated only two distinct clustering techniques, suggesting that both (Tocher and Single Linkage) were useful in the study of genetic divergence in corn. Nowadays, the UPGMA method is mostly suggested to study genetic traits of a population (Silva and Dias, 2013); however, the efficiency of other clustering methods to evaluate sweet corn germplasm is unknown.

The objective was to determine the best method to identify promising genotypes to obtain segregant populations and improve sweet corn production, using four distinct hierarchical dendograms and Tocher's optimization method, based on Euclidian distance of 181 sweet corn genotypes, with two methods of data standardization.

\section{MATERIAL AND METHODS}


The experiment was conducted at the Vegetable Experiment Station of Federal University of Uberlândia (UFU), located in Monte Carmelo - Brazil (18 42'43.19" S; $47^{\circ} 29^{\prime} 55.8$ " W; $873 \mathrm{~m}$ above sea level), during the years of 2016 and 2017. The soil presented the following characteristics: $\mathrm{pH}\left(\mathrm{H}_{2} \mathrm{O}\right)=5.9 ; \mathrm{P}$ available $=30.1 \mathrm{mg} \cdot \mathrm{dm}^{-3} ; \mathrm{K}^{+}=$ $0.22 \mathrm{cmol}_{\mathrm{c}} \cdot \mathrm{dm}^{-3} ; \mathrm{Ca}^{+2}=2.8 \mathrm{cmol}_{\mathrm{c}} \cdot \mathrm{dm}^{-3} ; \mathrm{Mg}^{+2}=1.0 \mathrm{cmol}_{\mathrm{c}} \cdot \mathrm{dm}^{-3} ; \mathrm{H}+\mathrm{Al}$ exchangeable $=$ $3.40 \mathrm{cmol}_{\mathrm{c}} \cdot \mathrm{dm}^{-3} ;$ organic matter $=4.2$ dag. $\mathrm{kg}^{-1} ;$ Index SMP $=3.40 ; \mathrm{Al}^{+3}=0.0 \mathrm{cmol}_{\mathrm{c}} \cdot \mathrm{dm}^{-3}$; CEC pH $7.0=7.42 \mathrm{cmol}_{\mathrm{c}} \cdot \mathrm{dm}^{-3}$; base saturation in $\mathrm{CEC}$ in $\mathrm{pH} 7.0=54 \%$; effective saturation by aluminum in $\mathrm{CEC}=0 \% ; \mathrm{Cu}^{+2}=2.3 \mathrm{mg} \cdot \mathrm{dm}^{-3} ; \mathrm{Zn}^{+2}=6.6 \mathrm{mg} \cdot \mathrm{dm}^{-3} \mathrm{e} \mathrm{Mn}^{+2}=6.6$ mg.dm ${ }^{-3}$.

The genetic material consisted of 181 open-pollinated sweet corn genotypes (S3) that belonged to the UFU's germplasm bank. The sowing was carried out on November 19, 2016. The experimental design was a complete randomized block design with two replications. The spacing between rows was of $0.9 \mathrm{~m}$ and the plots were consisted of two lines with four meters each. The experimental area was previously prepared by a conventional farming system. Sowing and groove fertilization were done manually. The planting and cover fertilization were performed as recommended for the crop and according to the soil analysis.

The following characteristics were evaluated between the stages of full female flowering (silking - R1 and blister - R2): plant height $(\mathrm{cm})$ at 76 days after sowing (DAS); leaf number per plant at 78 DAS; cob insertion height $(\mathrm{cm})$ at 80 DAS; number of cobs per plant at 88 DAS; days to silking; chlorophyll index (SPAD) on leaf at 81 DAS, using the chlorophyll determiner MINOLTA SPAD-502. Productivity variables were collected at maturity stage (R6): seed number per cob after threshing; production per cob (g); 1000 seeds weight $(\mathrm{g})$; and plant production $(\mathrm{g})$.

The data were subjected to analysis of variance by $\mathrm{F}$ test $(\mathrm{P}$-value $\leq 0.05)$. Then, multivariate analyzes were carried out to determine the genetic dissimilarity between the genotypes, obtaining the matrix of dissimilarity by the Euclidean distance. Prior to calculating the distance between matrices, two data standardizations were performed for comparison. The standardization $\mathrm{Z}$ score $\left(\mathrm{Z}_{1}\right)$ was performed by:

$$
Z_{1}=\left(\frac{X-X_{i}}{s}\right)
$$

where $X$ was the original value, $X_{i}$ was the mean and $s$ was the standard deviation. Therefore, the transformed values present the mean equal to zero and the variance equal to one (Romesburg, 1984). The second standardization $\left(\mathrm{Z}_{2}\right)$ was calculated as:

$$
Z_{2}=\frac{X}{S}
$$

The formula $Z_{2}$ produces transformed values with variance equal to one and a mean equal to $\bar{X} / s$. Genetic divergence was represented by four distinct hierarchical methods: Unweighted Pair-Group Method Using Arithmetic Averages (UPGMA), Ward, Weighted Pair-Group Method Using Arithmetic Averages (WPGMA) and Single Linkage. The Tocher's optimization method was also measured. The relative contribution of the quantitative traits was calculated according to Singh (1981). In order to validate the clusters, in other words, to verify the ability of the method to reproduce dissimilarity matrices, the cophenetic correlation coefficient (CCC) was estimated. The package NbClust (Charrad et 
al., 2014) was used to determine the best number of clusters, based on 24 indexes that establish the criteria of compactness and separation between clusters. The data was analyzed using the R software version 3.4.1.

\section{RESULTS}

All the evaluated traits presented statistical difference by $\mathrm{F}$ test (P-value $\leq 0.05)$, expressing the genetic variability in the 181 sweet corn genotypes. The ANOVA results confirmed that the sweet corn genotypes, from the Germplasm Bank of UFU, can be explored for breeding. The coefficient of variation $(\mathrm{CV})$ was lower than $3 \%$ for all the traits, indicating high experimental precision, except for seed weight with a CV of $32.1 \%$.

The most important characteristic for genetic divergence, according to the Singh (1981) criterion, for $Z_{1}$ standardization was plant height, with $26.5 \%$ (Table 1). On the other hand, the characteristic that contributed least to genetic divergence among the genotypes was seed weight, with $0.3 \%$. The evaluation of this characteristic can be eliminated in future trials, given its low contribution to genetic divergence and laborious measurement. For $\mathrm{Z}_{2}$ standardization, days to silking was the most influential variable in the distances estimation, with $64.4 \%$ of contribution, in contrast to $Z_{1}$, which was one of the least important traits, with $0.4 \%$. The large variation in the contribution of characters between the two matrices justifies that $Z_{1}$ standardization maintains all the values in the scale between zero and one, while the $Z_{2}$ standardization allows greater variation of the data by the division of the means by the standard deviation, which led the values of days to silking to be superior than the other means, with an overlap of variables by this method.

Table 1. Relative contribution of 10 agronomic traits to the genetic diversity of 181 sweet corn genotypes, according to Singh's criterion (Singh, 1981).

\begin{tabular}{|c|c|c|c|c|c|}
\hline Variable & $\begin{array}{l}(\%) \\
Z_{1}\end{array}$ & $\mathbf{Z}_{2}$ & Variable & $\begin{array}{l}(\%) \\
Z_{1}\end{array}$ & $\mathbf{Z}_{2}$ \\
\hline $\mathrm{PH}$ & 26.5 & 1.5 & DS & 0.4 & 64.4 \\
\hline $\mathrm{LN}$ & 7.3 & 16.6 & SN & 13.5 & 0.5 \\
\hline $\mathrm{HC}$ & 13.6 & 5.6 & $\mathrm{PC}$ & 10.8 & 0.7 \\
\hline $\mathrm{CN}$ & 9.0 & 3.0 & SW & 0.3 & 3.5 \\
\hline SPAD & 12.1 & 3.2 & PROD & 6.5 & 1.0 \\
\hline
\end{tabular}

PH: plant height; LN: leaf number per plant; $\mathrm{HC}$ : cob insertion height; CN: number of cobs per plant; DS: days to silking; SPAD: chlorophyll index; SN: seed number per cob after threshing; PC: production per cob; SW: 1000 seeds weight; PROD: plant production.

For the Euclidean matrix of the $\mathrm{Z}_{1}$ standardization, fourteen indexes of the Nbclust function indicated the formation of two to four clusters. For $Z_{2}$ standardization, ten indexes indicated the formation of two clusters. The cutting of the dendrograms was done looking for the formation of the clusters recommended by the Nbclust indexes. Although the Nbclust indexes suggested the formation of up to four clusters, Tocher's optimization method presented the formation of six clusters, based on the $Z_{1}$ standardized matrix (Table 2). With CCC value closed to the dendrograms (Table 3 ), the method isolated genotype 2, genotypes 19 and 111, genotypes 108 and 172, and created three more large clusters (Table 2). 
Table 2. Clustering of 181 sweet corn (Zea mays subsp. saccharata) genotypes by Tocher's optimization procedure from the Euclidean distances obtained based on 10 agronomic traits standardized by Z-scores $\left(\mathrm{Z}_{1}\right)$ and by the mean standard deviation $\left(\mathrm{Z}_{2}\right)$.

\begin{tabular}{|c|c|c|}
\hline & $\mathbf{Z}_{1}$ & $\mathbf{Z}_{2}$ \\
\hline Cluster 1 & 2 & 2 \\
\hline Cluster 2 & 19111 & Other genotypes \\
\hline Cluster 3 & 108172 & \\
\hline Cluster 4 & $12 \quad 12414023 \quad 57 \quad 34 \quad 10 \quad 73$ & \\
\hline Cluster 5 & $\begin{array}{lllllllllllll}76 & 107 & 27 & 115 & 98 & 37 & 156 & 135 & 36 & 81 & 55 & 46 & 146\end{array}$ & \\
\hline Cluster 6 & Other genotypes & \\
\hline
\end{tabular}

Table 3. Coefficients of co-phenetic correlation (CCC) obtained between the matrix of average Euclidean distances and the matrix of co-phenetic distances for the different hierarchical methodologies by Z-scores $\left(\mathrm{Z}_{1}\right)$ and by the mean standard deviation $\left(\mathrm{Z}_{2}\right)$ standardization for analysis of sweet corn varities.

\begin{tabular}{lll}
\hline Methodology & $\mathbf{C C C}$ & \\
\hline Single Linkage & $\mathbf{Z}_{\mathbf{1}}$ & $\mathbf{Z}_{2}$ \\
UPGMA & 0.51 & 0.66 \\
WPGMA & 0.65 & 0.77 \\
Ward & 0.52 & 0.66 \\
Tocher & 0.45 & 0.36 \\
\hline
\end{tabular}

Considering as a cut-off rule, the index between 60 and $70 \%$ of similarity, dendrograms by Simple linkage's and UPGMA's methods were efficient in determining four different clusters, also isolating genotype 2 (Figure 1). Genotype 111 was also isolated and genotypes 46 and 81 formed a new group that was not detected by the Tocher's method. The WPGMA's method was able to isolate genotypes 2 and 111 in different clusters and created three clusters with the rest of the genotypes. Ward's method was not able to isolate any genotypes, creating six clusters. Regarding CCC, the UPGMA's method was the most reliable of all the methods used, with $65 \%$, and Ward's method less efficient, with $45 \%$ (Table 3).

On the other hand, based on $Z_{2}$ standardized matrix, Tocher's method allowed the formation of two clusters, only isolating the genotype 2 (Table 2). The number of clusters formed was the same as those recommended by the NbClust indexes; however the CCC value was low, with $47 \%$ of similarity, smaller than the same method for the $Z_{1}$ standardization $(55 \%)$. Considering as a cut-off rule, the index between 70 and $80 \%$ of similarity, the dendrograms simple linkage and UPGMA also produced two clusters, isolating the genotype 2 (Figure 2). The WPGMA's method isolated genotype 2, but divided the remaining genotypes into two clusters (Figure 2). The Ward's method created five clusters and did not isolate any genotype (Figure 2). The standardized $\mathrm{Z}_{2}$ matrix produced higher CCC values, with the exception of the Ward's method, which had a CCC of $36 \%$, the lowest of all methods used (Table 3 ).

The standardized $Z_{2}$ matrix indicated that the genetic basis of the germplasm bank was narrow. The standardized $Z_{1}$ matrix allowed a larger group of genotypes to be isolated, resulting in the possibility of greater cross-breeding combinations in the hybrid exploration. The comparison between the Tocher's optimization method and the hierarchical 
dendograms demonstrated the ability to identify a high number of clusters with the dendrograms. Therefore, this increased the chances to find genetic divergence, especially if the $\mathrm{Z}_{2}$ standardized matrix is used.
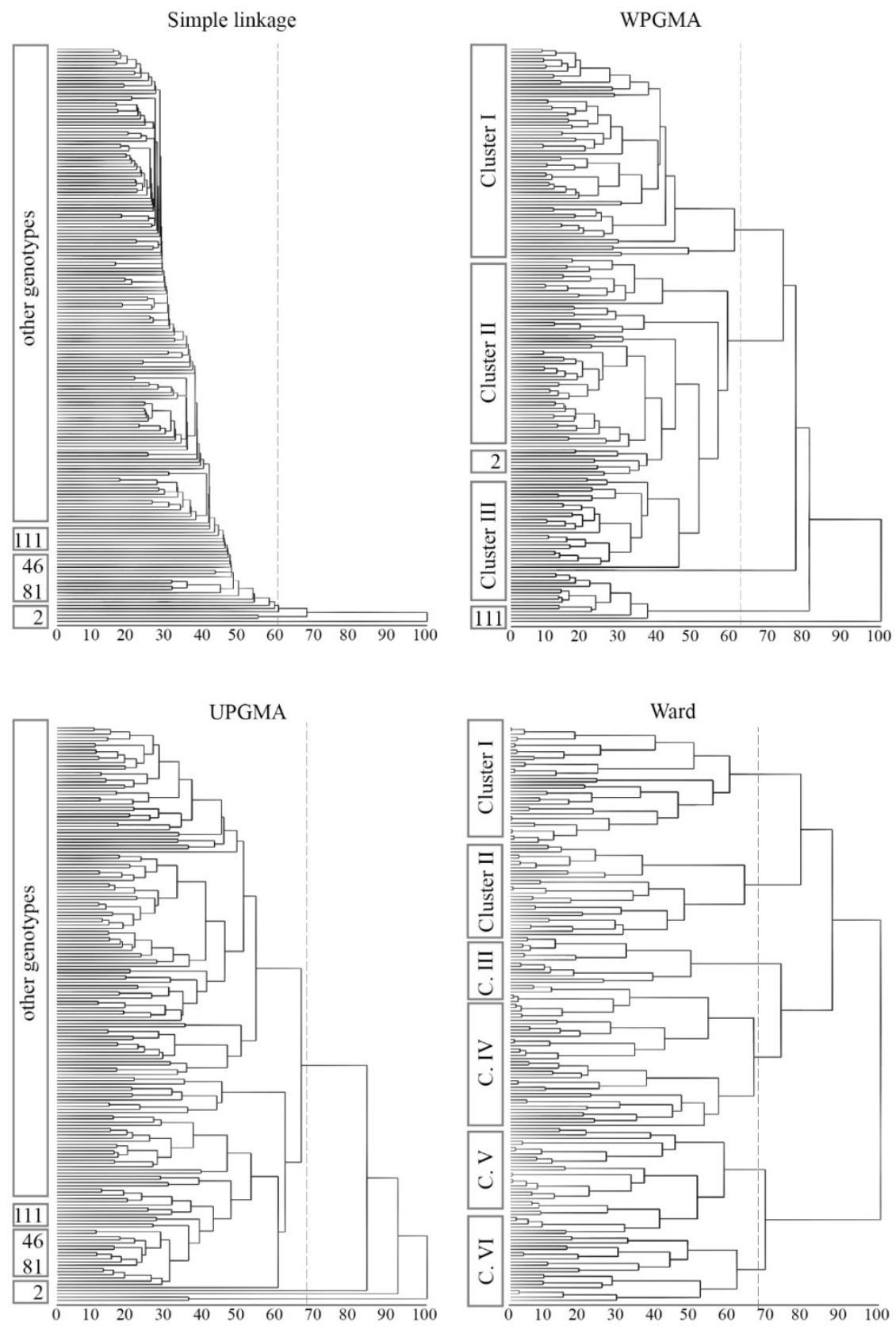

Figure 1. Clustering of 181 sweet corn genotypes using the Simple linkage, WPGMA, UPGMA and Ward method, from the Euclidean distances obtained based on 10 agronomic traits standardized by $\mathrm{Z}$-scores $\left(\mathrm{Z}_{1}\right)$. 
Simple linkage

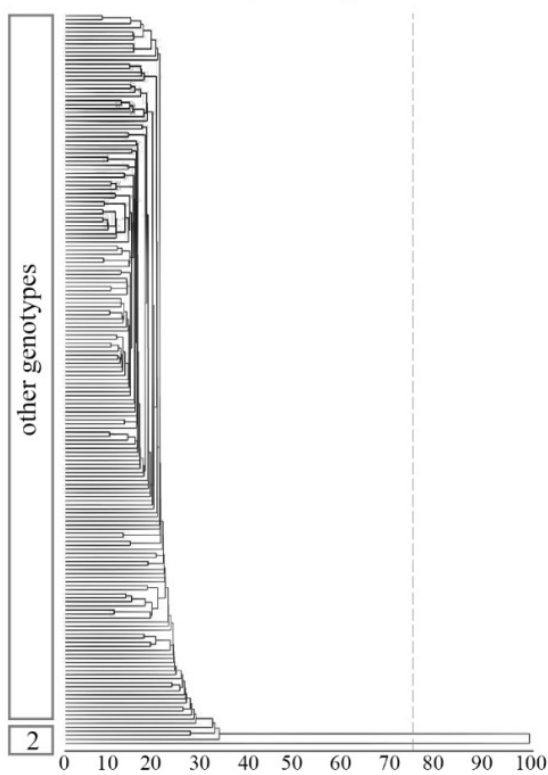

UPGMA

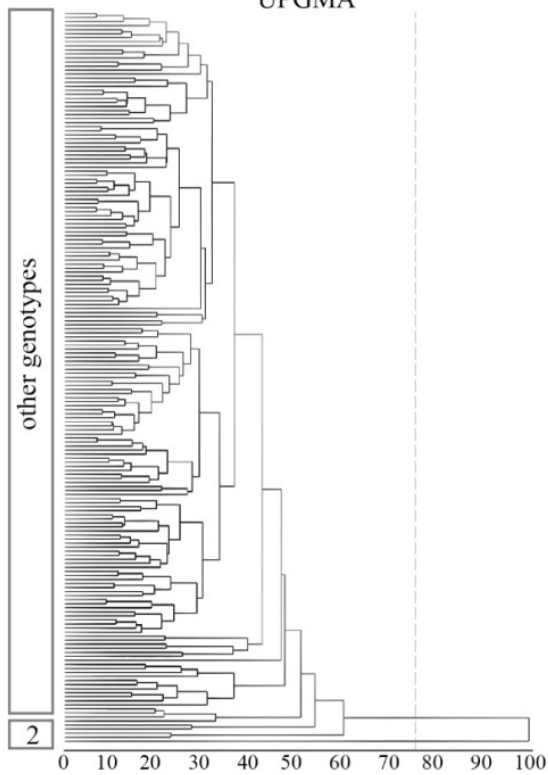

WPGMA
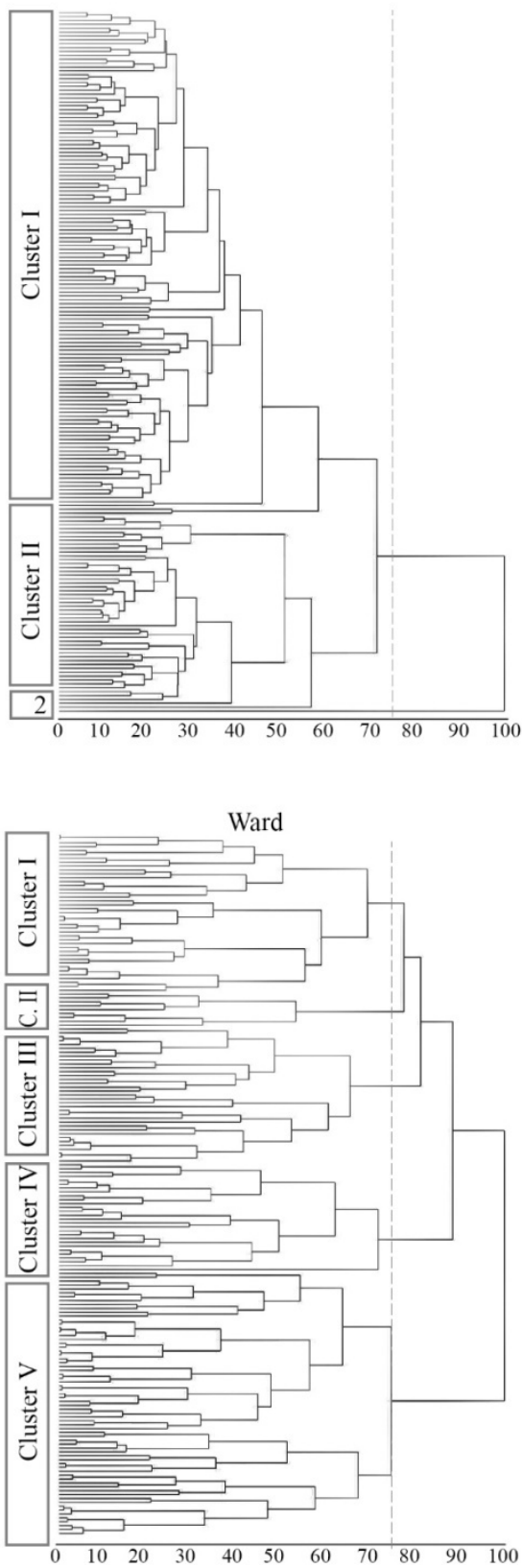

Figure 2. Clustering of 181 sweet corn genotypes using the Simple linkage, WPGMA, UPGMA and Ward methods, from the Euclidean distances obtained based on 10 agronomic traits standardized by dividing the values by the mean standard deviation $\left(\mathrm{Z}_{2}\right)$. 


\section{DISCUSSION}

Sweet corn is widely used for human consumption around the world. Because of the importance of sweet corn, breeders have been devoted to the improvement of sweetness and other valuable traits, such as yield, disease and insect resistance, and tolerance to environmental stress. Genetic combinations of the endosperm have allowed higher sugar content in sweet corn varieties and with longer shelf life in the market (Lertrat and Pulam, 2007).

Although there are several publications about genetic diversity in corn germplasm, few describe the genetic variability in sweet corn (Gerdes and Tracy, 1995; Amorim et al., 2003; Bered et al., 2005; Kashiani et al., 2010). Among the characteristics analyzed, only seed weight presented a very high $\mathrm{CV}$, greater than $28 \%$, according to the criteria proposed by Scapim et al. (1995) for corn traits.

Researches on the heritability of sweet corn traits indicated that plant height and days to silking are the ones of higher heritability, with 79.9 and $66.9 \%$ respectively (Kashiani et al., 2010). The $\mathrm{Z}_{1}$ standardized matrix considered plant height as one of the most important characters, but days to silking had little contribution in the Euclidean distance of the standardized matrices. For $Z_{2}$ standardized matrix, the inverse occurred for these traits. However, the overestimation for days to silking was estimated in $64.4 \%$.

It is very common genetic dissimilarity studies apply only an agglomerative method, which leads to subjective results, given the difference between these methods (Fernandes et al., 2015). Therefore, it is advisable to use a variety of clustering methods in order to compare the results (Jackson et al., 1989; Rohlf, 1990). Our results confirm the need of more researches about the genetic diversity in sweet corn, in order to present data with a greater number of multivariate techniques.

Moreover, the use of microsatellite markers was efficient to analyze the genetic structure of sul sweet corn progenies with SSR markers, allowing estimating the genetic distance or similarity between the progenies (Lopes et al., 2014). Further studies combining the evaluation of morphological traits with microsatellite markers should be performed.

The dendrograms identifieded contrasting genotypes for future crosses. The first cluster in a dendrogram is formed by the genotypes that present the greatest similarities (Cruz et al., 2014). Clusters formed by a single individual suggest that the material is more divergent from the others. It was observed in all methods that genotype 2 was the most contrasting and for some methods, the genotypes 46, 81 and 111 were highlighted for future crosses. Parental selection should be based on the magnitude of the genetic divergence among the genotypes, when the objective is to perform crosses resulting from superior progenies in relation to the characteristics of interest (Abreu et al., 2004).

Rotili et al. (2012) recommend the use of the Single Linkage method with the Tocher's method for maize genotypes. Our results showed that inference through dendrograms is safer and less restricted and the UPGMA and Single Linkage methods are more useful and reliable. Cantelli et al. (2016) obtained similar results to our study in soybean, in which the UPGMA and Single Linkage methods were superior when compared to the other clustering methods. Moreover, the results of Vogt et al. (2010) converged in similarity to the UPGMA's and Tocher's methods.

Although it is a requirement that the database has to be standardized when the variables came from different measurements (Hair Junior et al., 2009), many researchers 
forget about this procedure or execute it without knowing. There are no publications that reveal the impact of data transformation on cluster analysis, though there are several types of standardization. Our results showed that large differences were obtained using different forms of standardization. The standardization procedure $\mathrm{Z}_{1}$ was superior to several other standardizations when used with the Ward's method (Milligan and Cooper, 1988). In fact, the only dendrogram with higher CCC using $\mathrm{Z}_{1}$ standardization, was the Ward's method.

The Simple Linkage and UPGMA methods presented similar groupings, consistent with the aims of a breeding program and with the highest vales of CCC, being recommended for the study of genetic diversity in sweet corn. Ward's method was not efficient, because it created several clusters without isolating different genotypes. Furthermore, it was the method with the lowest CCC for both matrices. The standardized $\mathrm{Z}_{2}$ matrix should be avoided, especially when a large number of genetic traits are measured, in order to prevent possible overlapping between the traits, as variables with higher standard variations could contribute more to the clustering.

\section{ACKNOWLEDGMENTS}

The authors would like to thank CNPq and FAPEMIG for funding this study.

\section{CONFLICTS OF INTEREST}

The authors declare no conflict of interest.

\section{REFERENCES}

ABCSEM - Associação Brasileira de Comércio de Sementes e Mudas (2014). 2 $2^{\circ}$ Levantamento de dados socioeconômicos da cadeia produtiva de hortaliças no Brasil - Ano base 2012. Available at: [http://www.abcsem.com.br/imagens_noticias/Apresenta\%C3\%A7\%C3\%A3o\%20completa\%20dos\%20dados\%20 da\%20cadeia\%20produtiva\%20de\%20hortali\%C3\%A7as\%20-\%2029MAIO2014.pdf]. Accessed 12 July 2019.

Abreu FB, Leal NR, Rodrigues R, Amaral Junior AT, et al. (2004). Divergência genética entre acessos de feijão-devagem de hábito de crescimento indeterminado. Hortic. Bras. 22: 547-552.

Amaral Júnior AT, Gonçalves LSA, Freitas Júnior SP, Candido L, et al. (2013). UENF 14: a new popcorn cultivar. Crop Breed Appl. Biotechnol. 13: 218-220. doi: 10.1590/S1984-70332013000300013.

Amorim EP, Almeida CCS, Sereno MJCM, Bered F, et al. (2003). Genetic variability in sweet corn using molecular markers. Maydica. 48: 177-181.

Bered F, Terra TF, Spellmeier M and Barbosa Neto JF (2005). Genetic variation among and within sweet corn populations detected by RAPD and SSR markers. Crop Breed Appl. Biotechnol. 5: 418-425. doi: 10.12702/19847033.v05n04a07.

Cantelli DAV, Hamawaki OT, Rocha MR, Nogueira APO, et al. (2016). Analysis of the genetic divergence of soybean lines through hierarchical and Tocher optimization methods. Genet. Mol. Res. 15: gmr.15048836. doi: 10.4238/gmr.15048836.

Charrad M, Ghazzali N, Boiteau V and Nikfans A (2014). NbClust: An R Package for Determining the Relevant Number of Clusters in a Data Set. J. Stat. Softw. 61: 1-36. doi: 10.18637/jss.v061.i06.

Cruz CD, Regazzi AJ and Carneiro PCS (2014). Modelos biométricos aplicados ao melhoramento genético. 3rd edn. UFV, Viçosa.

Ertiro BT, Twumasi-afriyie S, Blummel M, Fiesen D, et al. (2013). Genetic variability of maize stover quality and the potential for genetic improvement of fodder value. Field Crops Res. 153: 79-85. doi: 10.1016/j.fcr.2012.12.019.

Fernandes EH, Schuster I, Scapim CA, Vieira ESN, et al. (2015). Genetic diversity in elite inbred lines of maize and its association with heterosis. Genet. Mol. Res. 14: 6509-6517. doi: 10.4238/2015.June.12.3.

Freitas ILJ, Amaral Junior AT, Viana AP, Pena GF, et al. (2013). Ganho genético avaliado com índices de seleção e com REML/Blup em milho-pipoca. Pesq. Agropecu. Bras. 48: 1464-1471. doi: 10.1590/S0100-204X2013001100007.

Gerdes JT and Tracy WF (1994). Diversity of historically important sweet corn inbreds as estimated by RFLPs, morphology, isozymes, and pedigree. Crop. Sci. 34: 26-33. doi: 10.2135/cropsci1994.0011183X003400010004x. 
Hair Junior JF, Black WC, Babin BJ, Anderson RE, et al. (2009). Análise multivariada de dados. 6th edn. Bookman, Porto Alegre.

Jackson DA, Somers KM and Harvey HH (1989). Similarity coefficients: Measures of co-occurrence and association or simply measures of occurrence. Am. Nat. 133: 436-453. doi: 10.1086/284927..

Kashiani P, Saleh G, Abdullah NAP and Abdulah SN (2010). Variation and Genetic Studies on Selected Sweet Corn Inbred Lines. Asian J. Res. Crop. Sci. 2: 78-84. doi: 10.3923/ajcs.2010.78.84.

Lertrat K and Pulam T (2007). Breeding for increased sweetness in sweet corn. Int. J. Plant Breed. 1: 27-30.

Lopes AD, Scapim CA, Mangolin CA and Machado MFPS (2014). Genetic divergence among sweet corn lines estimated by microsatellite markers. Genet. Mol. Res. 13: 10415-10426. doi: 10.4238/2014.December.12.3.

Milligan GW and Cooper MC (1988). A study of Standardization of Variables in Cluster Analysis. J. Classif. 5: 181204. doi: 10.1007/BF01897163.

Moterle LM, Braccini AL, Scapim CA, Pinto RJB, et al. (2012). Combining ability of popcorn lines for seed quality and agronomic traits. Euphytica. 185: 337-347. doi: 10.1007/s10681-011-0458-2.

Pena GF, Amaral Júnior AT, Gonçalves LSA, Candido LS, et al. (2012). Stability and adaptability of popcorn genotypes in the State of Rio de Janeiro, Brazil. Genet. Mol. Res. 11: 3042-3050. doi: 10.4238/2012.August.31.1.

Rangel RM, Amaral Junior AT, Viana AP, Freitas Junior SP, et al. (2007). Prediction of popcorn hybrid and composite means. Crop Breed Appl. Biotechnol. 7: 288-296.

Ribeiro RM, Amaral Junior AT, Gonçalves LSA, Candido LS, et al. (2012). Genetic progress in the UNB-2U population of popcorn under recurrent selection in Rio de Janeiro, Brazil. Genet. Mol. Res. 11: 1417-1423. doi: 10.4238/2012.May.15.12.

Rigon JPG, Capuani S and Rigon CAG (2015). Genetic divergence among maize hybrids by morphological descriptors. Bragantia. 74: 156-160. doi: 10.1590/1678-4499.0246.

Rohlf FJ (1990). Morphometrics. Annu. Rev. Ecol. Evol. Syst. 21: 299-316. doi: 10.1146/annurev.es.21.110190.001503.

Romesburg HC (1984). Cluster Analysis for Researchers. Lifetime Learning Publications, Belmont.

Rotili EA, Cancellier LL, Dotto MA, Peluzio JM, et al. (20120). Divergência genética em genótipos de milho, no Estado do Tocantins. Rev. Cienc. Agron. 43: 516-521. doi: 10.1590/S1806-66902012000300014.

Scapim CA, Carvalho CGP and Cruz CD (1995). Uma proposta de classificação dos coeficientes de variação para a cultura do milho. Pesq. Agropecu. Bras. 30: 683-686.

Silva AR and Dias CTS (2013). A cophenetic correlation coefficient for Tocher's method. Pesq. Agropecu. Bras. 48: 589-596. doi: 10.1590/S0100-204X2013000600003.

Silva DFG, Coelho CJ, Romanek C, Gardingo JR, et al. (2016). Dissimilaridade genética e definição de grupos de recombinação em progênies de meios-irmãos de milho-verde. Bragantia. 75: 401-410. doi: 10.1590/16784499.343.

Silva GC, Oliveira FJ, Anunciação Filho CJ and Simões Neto DE (2011). Divergência genética entre genótipos de canade-açúcar. Rev. Bras. Ciênc. Agrár. 6: 52-58. doi: 10.5039/agraria.v6i1a848.

Singh D (1981). The relative importance of characters affecting genetic divergence. Indian J. Genet. Plant Breed. 41: 237-245.

Vittorazzi C, Amaral Júnior AT, Gonçalves LSA, Candido LS, et al. (2013). Selecting pre-cultivars of popcorn maize based on nonparametric indices. Rev. Cienc. Agron. 44: 356-362. doi: 10.1590/S1806-66902013000200019.

Vogt GA, Balbinot Júnior AA and Souza AM (2010). Divergência genética entre cultivares de girassol no Planalto Norte Catarinense. Sci. Agrar. 11: 307-315. 